\title{
ANALISIS PENDAPATAN ANGGOTA TNI AD TERHADAP PEMENUHAN KEWAJIBAN ZAKAT,INFAQ DAN SHADAQAH.
}

\section{MEMBERS OF THE ARMY REVENUE ANALYSIS OF COMPLIANCE OBLIGATIONS ZAKAT, INFAQ AND SADAQAH. Siska Afrianti ${ }^{1}$ Rully Trihantana ${ }^{2}$}

\author{
1 Program Studi Ekonomi Islam Fakultas Ekonomi Islam Universitas Djuanda, Jl. Tol Ciawi \\ No. 1, Kotak Pos 35 Bogor 16770 \\ 2 Program Studi Ekonomi Islam Fakultas Ekonomi Islam Universitas Djuanda, Jl. Tol Ciawi \\ No. 1, Kotak Pos 35 Bogor 16770
}

\begin{abstract}
Army KOREM GAPU DENPAL B in Jambi is a study to see the fulfillment of the obligation of zakat and sadaqah infaq committed by members of the Army of the income he earned. The magnitude of the fulfillment of Zakat, Sadaqah infaq and issued by a member of the Army adjusted the amount of their earned income.This study aims to determine how much income effect DENPAL B Members of the Army to fulfill the obligation of zakat and sadaqah, infaq (final spending). Data collection techniques using observation techniques, interviews, questionnaires, and literature. Analysis of the data used is descriptive quantitative descriptive statistics, linear regression and correlation methods.

The results of this study indicate that the income of the Army DENPAL B is very large influence on the fulfillment of the obligation of zakat and sadaqah infaq. This is evident from the results of correlation calculations. Authors using SPSS version 16.0 and obtained values of $r=0.913 \%$, which means there is a very high influence of income to the fulfillment of the obligation of zakat and sadaqah infaq (final spending) in the Army in KOREM GAPU Jambi.
\end{abstract}

Keywords : Income TNI AD, Final Spending

\section{ABSTRAK}

TNI AD DENPAL B di KOREM GAPU merupakan objek penelitian untuk melihat pemenuhan kewajiban zakat, infaq dan shadaqah yang dilakukan anggota TNI AD dari pendapatan yang diperolehnya. Besarnya pemenuhan zakat, infaq dan shadaqah yang dikeluarkan oleh anggota TNI AD disesuaikan dengan besarnya pendapatan yang diperoleh mereka. Penelitian ini bertujuan untuk mengetahui berapa besar pengaruh pendapatan Anggota TNI AD DENPAL B terhadap pemenuhan kewajiban zakat, infaq dan shadaqah (final spending). Teknik pengumpulan data menggunakan teknik observasi, wawancara, kuisioner, dan kepustakaan.Analisis data yang digunakan adalah deskriptif kuantitatif dengan statistik deskriptif, metode regresi linear dan korelasi.

Hasil dari penelitian ini menunjukkan bahwa pendapatan TNI AD DENPAL B sangat besar pengaruhnya terhadap pemenuhan kewajiban zakat, infaq dan shadaqah.Hal ini terlihat dari hasil perhitungan korelasi.diperoleh nilai $r=0,913 \%$, yang artinya ada pengaruh yang sangat tinggi antara pendapatan dengan pemenuhan kewajiban zakat, infaq dan shadaqah (final spending) pada TNI AD di KOREM GAPU Jambi.

Afrianti. 2012. Analisis Pendapatan TNI ADTerhadap Pemenuhan Kewajiban Zakat, Infaq dan Shadaqah.Jurnal Syariakah1(1): 48 - 61 . 


\section{PENDAHULUAN}

Memberi nafkah pada anak dan keluarga secara layak merupakan salah satu ikhtiar penting yang harus kita lakukan dengan sepenuh hati.Bekerja dengan ikhlas dan penuh dedikasi demi mendapat pendapatan atau income yang memadai tentu juga merupakan sebuah rangkaian ibadah yang mesti kita rawat dengan penuh keteguhan.

Dalam rangka pemenuhan kebutuhan konsumsi rumah tangga, pendapatan berpengaruh terhadap konsumsi rumah tangga dan tabungan.Dalam hal ini, pendapatan juga memiliki pengaruh terhadap pemenuhan kewajiban seseorang untuk membayar zakat, infaq dan shadaqah (final spending).Sebagaimana dijelaskan dalam konsep syariah bahwa pendapatan itu digunakan untuk konsumsi, tabungan dan juga untuk belanja akhirat atau bisa juga dikatakan sebagai tabungan di akhirat kelak. Adapun tabungan untuk akhirat tersebut berupa pemenuhan kewajiban

zakat, infaq dan shadaqah (final spending).

Melalui aktivitas ekonomi kita memperoleh pendapatan, pendapatan merupakan masalah yang berkenaan dengan uang. Pendapatan memiliki keanekaragaman dalam cara memperolehnya. Karir seseorang sangat menentukan hasil pendapatan yang diterima, hal tersebut memberi pengaruh kepada pemenuhan kewajiban zakat, infaq dan shadaqah.

Melalui uraian diatas,tingkat pendapatan pegawai terhadap pemenuhan kewajiban zakat, infak dan shadaqah merupakan interaksi edukatif, hal tersebut bisa terbukti dari hasil prasurvey yang peneliti lakukan pada Tentara Nasional Indonesia Angkatan Darat bagian Detasemen Peralatan B (TNI AD DENPAL B) di Komando Resort Militer Garuda Putih (KOREM GAPU) Jambi. Dari prasurvey tersebut terlihat adanya dampak positif terhadap pemenuhan kewajiban ZIS.

\section{MATERI DAN METODE}

a. Konsep Pendapatan Menurut Ilmu Ekonomi

Konsep pendapatan menurut ilmu ekonomi dikemukakan oleh Wild "Pendapatan adalah arus masuk atau penghasilan nilai aktiva suatu perusahaan atau pengurangan kewajiban yang berasal dari aktivitas utama atauinti perusahaan yang masih berlangsung"(Wild:2005).

Pada dasarnya konsep pendapatan menurut ahli ilmu akuntansi dapat ditelusuri dari 2 (dua) sudut padang, yaitu

1. Pandangan yang menekankan pada pertumbuhan atau peningkatan jumlah aktiva yang timbul sebagai hasil dari kegiatan operasional perusahaan pendekatan yang memusatkan perhatian kepada arus masuk atau inflow.

2.Pandangan yang menekankan kepada penciptaan barang dan jasa oleh perusahaanserta penyerahan barang dan jasa atau outflow. Dalam PSAK nomor 23 paragraf 06 Ikatan Akuntan Indonesia (2004, 23.2) menyatakan bahwa "Pendapatan adalah arus kas masuk bruto dari manfaat ekonomi yang timbul dari aktivitas normal perusahaan selama satu periode bila arus masuk itu mengakibatkan kenaikan ekuitas yang tidak berasal dari kontribusi modal"(IkatanAkuntansi

Indonesia:2004).

Menurut Keyness faktor terpenting yang menentukan besarnya pengeluaran rumah tangga baik perorangan maupun keseluruhan adalah pendapatan (income $=$ $\mathrm{Y})$. Income (Y) pada suatu waktu tertentu secara sederhana dapat digunakan untuk keperluan konsumsi (comsumption $=\mathrm{C}$ ) dan ditabung (Saving $=$ S) (Teddy Herlambang :2001). Secara matematisnya yaitu:

$\mathrm{Y}=\mathrm{C}+\mathrm{S}$

Dimana $\mathrm{Y}=$ Pendapatan 


$$
\begin{aligned}
& \mathrm{C}=\text { Konsumsi } \\
& \mathrm{S}=\text { Tabungan }
\end{aligned}
$$

b. Konsep Pendapatan Menurut Ekonomi Islam

Menurut Adiwarman Karim bahwa pendapatan dalam Ekonomi Islam adalah penjumlahan konsumsi dan final spending, dengan persamaan matematisnya yaitu:

$$
\mathrm{Y}=\mathrm{FS}+\mathrm{S}
$$

Dimana $\mathrm{Y}=$ Pendapatan

$\mathrm{FS}=\mathrm{C}+$ Infak

FS =Final Spending di jalan Allah SWT

$\mathrm{S}=$ Tabungan

Pernyataan Standar Akuntansi

Keuangan membagi pendapatan menjadi tiga jenis yaitu :

a. Penjualan barang

Barang, meliputi barang yang diproduksi perusahaan untuk dijual dan barang yang dibeli pengecer atau tanah dan properti lain yang dibeli untuk dijual kembali

b. Penjualan jasa

Penjualan jasa, biasanya menyangkut pelaksanaan tugas secara kontraktual telah disepakati untuk dilaksanakan selama suatu periode waktu yang disepakati oleh perusahaan.Jasa dapat diserahkan selama satu periode atau lebih dari satu periode.

c. Penggunaan aktiva perusahaan oleh pihak-pihak lain yang menghasilkan bunga, royalti dan deviden.

Allah SWT menegaskan dalam Al-Qur'an surat Al-Baqarah ayat 267 yang Artinya :"Wahai orang-orang yang beriman, nafkahkanlah (di jalanallah) sebagian dari hasil usahamu yang baik-baik dan sebagian dari apa yang Kami keluarkan dari bumi untuk kamu. Dan janganlah kamu memilih yang buruk-buruk lalu kamu menafkahkan daripadanya, padahal kamu sendiri tidak mau mengambilnya melainkan dengan memincingkan mata terhadapnya. Dan ketahuilah, bahwa Allah Maha Kaya lagi Maha Terpuji,". (QS. Al-Baqarah : 2 :267)

Serta dalil lain surat At-Taubah ayat 34yang Artinya :"Dan orang-orang yang menyimpan emas dan perak dan tidak menginfaqkannya di jalan Allah SWT, maka berikanlah kabar gembira kepada mereka, bahwa mereka akan mendapat azab yang pedih.

Final Spending menurut pengertian dalam Ekonomi Islam adalah pembelanjaan akhirat dimana tujuannya itu untuk tabungan kita di akhirat kelak(Adi Warman Karim:2007). Final spending itu terdiri dari :

Zakat dari segi bahasa yaitu merupakan kata dasar (masdar) dari kata zaka yang berarti berkah, tumbuh, bersih dan baik(Yusuf Qaedawi). Zakat menurut bahasa artinya adalah berkembang atau bertambah(Wahbah Azzuhaili :2011).

Menurut bahasa infaq berasal dari kata anfaqa yang berarti mengeluarkan harta untuk kepentingan sesuatu.Sedangangkan menurut istilah syari'at, infaq adalah mengeluarkan sebagian harta yang diperintahkan dalam Islam.

Pengertian shadaqoh atau sedekah secara bahasa berasal dari kata "shadaqa" yang artinya "benar" tersurat dari kata ini bahwa yang bersedekah adalah orang yang benar imannya. Adapun secara terminologi syariat shadaqah adalah pemberian sukarela yang dilakukan oleh seseorang kepada orang lain, terutama kepada orangorang miskin, setiap kesempatan terbuka yang tidak ditentukan baik jenis, jumlah maupun waktunya, shadaqah tidak terbatas pada pemberian yang bersifat material saja tetapi juga dapat berupa jasa yang bermanfaat bagi orang lain. 


\section{Skema Kerangka Pemikiran}

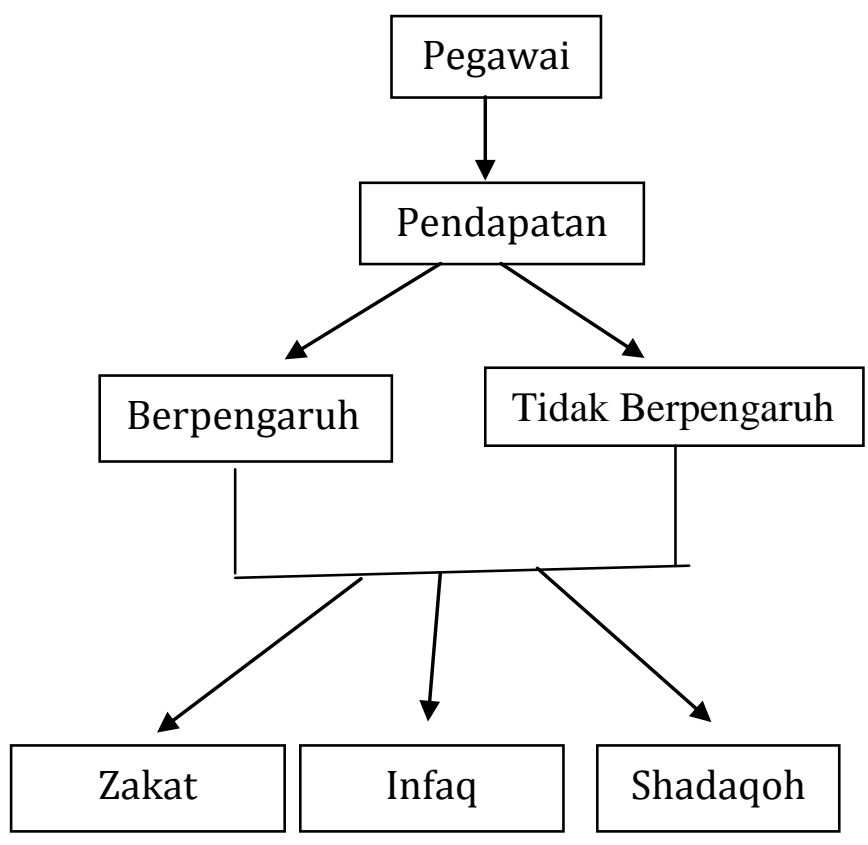

\section{Jenis Penelitian}

Penelitian yang dilakukan merupakan penelitian deskriptif kuantitatif, yaitu penelitian yang memberikan gambaran atau uraian atas suatu keadaan sejelas mungkin tanpa ada perlakuan terhadap obyek yang diteliti.

Populasi yang digunakan pada penelitian ini adalah anggota TNI AD DENPAL B di KOREM GAPU Jambi sebanyak 59 0rang.Sedangkan sampel pada penelitian ini adalah keseluruhan populasi yaitu sebanyak 59 orang.Dalam penelitian ini, teknik sampling yang digunakan adalah Stratified Random Sampling.

Objek penelitian adalah Anggota TNI AD DENPAL B di KOREM GAPU Jambi, dengan fokus penelitian yaitu tentang Analisis Tingkat Pendapatan Pegawai Terhadap Pemenuhan Kewajiban Zakat, Infaq dan Shadaqah (Final Spending).

Data primer merupakan sumber utama dalam penelitian ini dimana datanya adalah pendapatan anggota TNI AD DENPAL B di KOREM GAPU Jambi dan data zakat, infaq dan shadaqah yang dikeluarkan setiap bulannya.
Data sekunder yakni data pendukung yang diperoleh melalui dokumentasi, yang diperoleh dari berbagai literatur baik dalam bentuk buku, majalah, koran, internet dan yang lainnya yang memiliki keterkaitan dengan penelitian ini. Teknik pengumpulan data dengan:

1. Teknik observasi

2. Teknik wawancara

3. Teknik angket atau kuisioner

Teknik analisis yang penulis gunakan adalah deskriptif kuantitatif dan korelasi. Penelitian korelasi maksudnya adalah penelitian yang melihat hubungan antara variabel dimana dua atau lebih variabel diteliti untuk melihat hubungan yang terjadi diantara mereka tanpa coba untuk merubah atau mengadakan perlakuan terhadap variabel-variabel tersebut. Metode yang digunakan penulis adalah statistik deskriptif, metode regresi linear dan korelasi .

Tempat pelaksanaan penelitian ini adalah di Komplek TNI AD KOREM GAPU Jambi Jln. Jendral Urip Sumoharjo KOREM 042 Garuda Putih Telanai Pura Jambi.Waktu penelitian dimulai dari tanggal 27 sampai dengan 31 Januari 2012.

\section{HASIL DAN PEMBAHASAN}

\section{Gambaran Umum KOREM GAPU Jambi (DENPAL B)}

Jumlah responden yang diteliti adalah sebanyak 59 orang. Penelitian ini dilihat dari karakteristik TNI yang terdiri dari tingkat usia, tingkat pendidikan, status perkawinan, tingkat jabatan/pangkat, pendapatan, agama, dan alamat.

Dalam penelitian ini, untuk menguji hipotesis peneliti menggunakan regresi linier sederhana yang dimaksudkan untuk mengetahui pengaruh variabel bebas (independen) $\mathrm{X}$, terhadap variabel terikat (dependen) Y. Analisis ini digunakan untuk mengetahui pengaruh variabel $X$ yaitu pendapatan TNI terhadap variabel $Y$ yaitu zakat, infaq dan shadaqah.Data pendapatan ialah gaji TNI AD DENPAL B setiap bulannya.Sedangkan data zakat, infaq dan shadaqah ialah zakat penghasilan dan infaq, 
shadaqah yang dikeluarkan setiap bulannya.Berikut ini adalah data pendapatan dan zakat, infaq dan shadaqah setiap bulan dari TNI AD DENPAL B.

Perhitungan menggunakan metode regresi linier sederhana yang dihitung menggunakan program SPSS dengan hasil perhitungan sebagai berikut:

a. Descriptive Statistik

Statistika deskriptif adalah teknik yang digunakan untuk mensarikan data dan menampilkannya dalam bentuk yang dapat dimengerti oleh setiap orang. Hasil dari ini dapat memberikan pengetahuan yang signifikan pada kejadian atau fenomena yang belum dikenal dan mendeteksi keterkaitan yang ada di dalamnya(Pengertian statistik deskriptif:2011).

Pada tabel analisa statistik deskriptif di bawah ini, didapat nilai sebagai berikut:

Tabel 1.Descriptive Statistics

\begin{tabular}{ccr}
\hline Men & Std. Deviation & $\mathrm{N}$ \\
\hline 3507152.54 & 645848.781 & 59 \\
133289.44 & 43659.029 & 59 \\
\hline
\end{tabular}

Tabel di atas menyajikan dua variabel yaitu variabel Pendapatan (X) dan variabel ZIS (Y). Hasil deskriptif Pendapatan (X) dalam tabel descriptive statistics dijelaskan bahwa terdapat jumlah data $(\mathrm{N})=59$; rata - rata (mean) sebesar Rp 3.507.152,54 yang artinya bahwa besar pendapatan yang yang diperoleh oleh TNI AD DENPAL B KOREM GAPU Jambi setiap bulannya rata - rata adalah Rp 3.507.139,98 dan untuk simpangan baku (standar deviasi) $=\mathrm{Rp}$ $645.848,781$. Sedangkan variabel ZIS (X) dalam tabel dijelaskan dalam jumlah data (N) = 59; rata-rata (mean) sebesar Rp 133.289,44, artinya besar zakat, infaq dan shodaqoh yang dikeluarkan oleh TNI AD DENPAL B rata - rata adalah sebesar Rp 133.289,44 dan simpangan baku (standar deviasi) = Rp 43.659,029.

b. Nilai Koefisien determinasi
Koefisien determinasi adalah suatu alat ukur yang digunakan untuk mengetahui sejauhmana tingkat hubungan antara variabel $\mathrm{X}$ dan $\mathrm{Y}$.

\section{Tabel 2. Model Summary}

\begin{tabular}{lrlll}
\hline & & & Adjusted \\
& & \multicolumn{2}{c}{$\mathrm{R}$} & \multicolumn{1}{c}{ Std. Error } \\
Model & R & Square & Square & he Estimate \\
1 & $13^{\text {a }}$ & 834 & .831 & 7953.555 \\
\hline
\end{tabular}

Tabel 3.Anova

Change Statistic

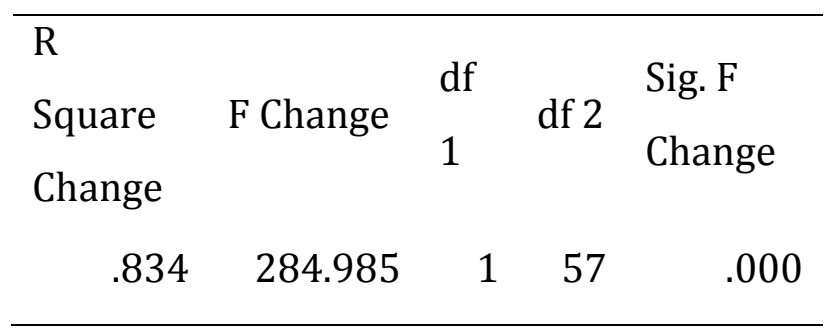

Pada bagian ini terdapat nilai $\mathrm{R}$ sebesar 0,913, menunjukkan bahwa korelasi/hubungan antara variabel $\mathrm{X}$ yaitu Pendapatan dengan variabel dependen yaitu ZIS sangat kuat atau sangat erat. Dimana faktor pendapatan dapat menjelaskan sebanyak 91,3\% ZIS yang dikeluarkan sedangkan sisanya sebesar 8,7 $\%$ dijelaskan oleh faktor lain.

Analisa of Varian adalah suatu metode analisis statistika yang termasuk ke dalam cabang statistika inferensi.ANOVA tergolong analisis komparatif lebih dari dua variabel atau lebih dari dua ratarata.Ia merupakan pengembangan dari masalah Behrens-Fisher, sehingga uji-F juga dipakai dalam pengambilan keputusan.

Dari uji ANOVA atau F-tes, didapat nilai $\mathrm{F}=285.985$ dengan tingkat signifikansi 0,000 . Karena probabilitas $(0,000)$ lebih kecil daripada 0,05, maka dapat dikatakan bahwa pendapatan secara signifikan sangat berpengaruh terhadap pemenuhan ZIS. 
Dengan menentukan level of significant $=5 \%(0,05)$ dan degree of freedom untuk df $1=2$ dan df $2=57$, diperoleh F-hitung

a. Koefisien Regresi

Pada bagian ini ditampilkan nilai koefisien regresi sehingga terbentuk persamaan regresi yaitu: $\mathbf{Y}=\mathbf{- 8 3 1 9 7 . 6 2 6}+\mathbf{0 , 0 6 2 X}+$ pembangunan ekonomi syariah

Dependent Variable: ZIS

Angka-angka ini dapat diartikan sebagai berikut:

1) Pada bagian ini dikemukakan nilai konstanta (a) $=-83197.626$ dan beta $=$ 0.062 serta harga t-hitung dan tingkat signifikansi $=0.000$. Konstanta sebesar - 89197.626 menyatakan bahwa jika tidak ada pendapatan, maka ZIS yang dikeluarkan adalah RP. -89197,626

2) Koefisien bernilai negatif, artinya meskipun tidak ada pendapatan, ZIS tetap dikeluarkan tetapi akan ada yang dikorbankan sehingga besar ZIS menjadi negative.

Nilai yang diperoleh adalah sebesar 0,913 yang berarti terdapat hubungan yang sangat erat atau sangat tinggi antara variabel pendapatan dan variabel ZIS.Untuk membuktikan hipotesis "terdapat hubungan yang sangat signifikan antara variabel $\mathrm{X}$ dan Y dapat dilihat dari nilai signifikansinya berdasarkan tabel korelasi.

Hasil diatas menunjukkan bahwa korelasi antara biaya promosi dan jumlah Dana pihak ketiga memimilki nilai $r=1$. 0.913. karena nilai $r$ terletak diantara 0.911.00, maka dapat diartikan bahwa hubungan antara pendapatan dan pemenuhan kewajiban ZIS adalah sangat erat atau sangat tinggi.

Dalam uji hipotesis menunjukkan bahwa $\mathrm{H}_{\mathrm{a}}$ dan $\mathrm{H}_{\mathrm{o}}$ ditolak, artinya pendapatan yang diperoleh TNI AD DENPAL B di KOREM GAPU Jambi sangat mempengaruhi besar pemenuhan kewajiban zakat, infaq dan shadaqah.

Dari hasil penelitian ini dapat diketahui bahwa pendapatan yang diperoleh TNI AD DENPAL B memberikan pengaruh yang besar terhaap pemenuhan kewajiban zakat, infaq dan shadaqah.Sehingga dapat dikatakan bahwa pendapatan mempunyai peranan penting dalam mempengaruhi besar pemenuhan kewajiban zakat, infaq dan shadaqah. Krena itu perlu adanya pendapatan agar bisa mengeluarkan ZIS tanpa ada yang harus dikorbankan dari yang dimiliki.

\section{KESIMPULAN DAN IMPLIKASI}

Pendapatan anggota TNI AD DENPAL B di KOREM GAPU Jambi dipengaruhi oleh tinggi rendahnya jabatan yang disandang oleh setiap anggota TNI.Hal tersebut juga mempengaruhi kepada pemenuhan kewajian zakat, infaq dan shadaqah final spending).Berdasarkan penelitian yang telah dilakukan, diketahui bahwa pendapatan sangat berpengaruh terhadap pemenuhan kewajiban zakat, infaq dan shadaqoh. Hal ini dapat dilihat dari hasil perhitungan yang dilakukan, maka didapat persamaan regresi yaitu: $\mathbf{Y}=\mathbf{- 8 3 1 9 7 . 6 2 6}$ $+\mathbf{0 , 6 2 X}+\mathbf{e}$. Ini menyatakan bahwa setiap anggota TNI AD bisa memenuhi kewajiban zakat, infaq dan shadaqah, tetapi apabila pendapatannya telah mencukupi dan mencapai nishab maka dia wajib mengeluarkan ZIS, sedangkan jika pendapatanya belum mencapai nishab maka boleh memenuhi kewajiban ZIS ini, namun akan ada yang dikurangi atau dikorbankan dari kebutuhannya.

Nilai $r$ sebesar 0.913 atau 91,3\% menunjukkan bahwa korelasi/hubungan antara pendapatan dengan variabel dependen yaitu zakat, infaq dan shadaqoh adalah sangat erat atau sangat tinggi. Hal ini menunjukkan bahwa pendapatan yang diperoleh sangat mempengaruhi zakat infaq dan shadaqoh yang dikeluarkan oleh TNI AD DENPAL B. Dengan demikian dalam uji hipotesa, menolak $\mathrm{H}_{0}$ dan menerima $\mathrm{H}_{\mathrm{a}}$ yang berarti pendapatan berpengaruh terhadap pemenuhan kewajiban zakat, infaq dan shadaqah. 


\section{DAFTAR PUSTAKA}

Az-Zuhaili, Wahbah, Fiqih Islam Wa Adillatuhu, (Jakarta : Gema Insani), 2011

Dyckman, Thomas R, Roland E. Dukes, and Charles J. Davis, AkuntansiIntermediate, Edisi ketiga, Alih bahasa : Munir Ali, Erlangga, Jilid I, Jakarta, 2000

Direktorat Jenderal Peraturan Perundangundangan Departemen Hukum Dan HAM, 2001, Lembaran Negara Republik Indonesia, http://www.djpp.depkumham.go.id/inc/ buka.php, Hotml 01 Mei 2012

Ensiklopedia Islam, 2010. Definisi Shadaqah. Diakses dari http:www.google.com. 5 Desember 2011

Hendriksen, Eldon S, Teori Akuntansi, Edisi keempat, terjemahan Gunawan Hutahuruk (Jakarta : Erlangga), 1999

Harnanto, Akuntansi Keuangan Menengah, Buku I, Cetakan keempat, Liberty, Yogyakarta, 2002

Ibrahim, 2009, Analisa Penyaluran Pembiayaan Berdasarkan Sektor Ekonomi Terhadap Tingkat Non Performing Financing (NPFs) Perbankan Syariah di Indonesia 2007-2008, Skripsi pada Fakultas Ilmu Pendidikan dan Studi Islam, UNIDA, BOGOR, tidak diterbitkan

Ikatan Akuntan Indonesia, Standar Akuntansi Keuangan Per 1 Oktober 2004 (Jakarta : Penerbit Salemba Empat), 2004

Karim, Adiwarman A, Ekonomi Mikro Islami (Jakarta : PT Raja Grafindo Persada), 2007

Kieso, Donald E, Jerry J. Weygandt, and Terry D. Warfield, Akuntansi
Intermediate, Edisi Kesepuluh, Alih bahasa : Herman Wibowo dan Ancella A. Hermawan, Erlangga, Jilid III, Jakarta, 2002

Laksono Budi,Tes Masuk TNI-POLRI (Yogyakarta : Pustaka Widyatama), 2011

Mohammada Jauhar, Buku Pintar Tes Masuk TNI/POLRI, (Jakarta : Prestasi Pustaka Jakarta), 2011

Mushaf Al-Qur'an Terjemah, (Jakarta : Gema Insani), 2005

News Wordprees Themes, 2011, Sejarah TNI, diambil dari http://sejarah.info/2011/12/sejarah-tni. hotml 20 Juni 2012

Nirmala, TA dan Pratama, AA, Kamus Lengkap Bahasa Indonesia (Surabaya : Prima Media), 2003

"Muhammadinah, Pengertian Pendapatan dan Beban, 2010diambil dari http://definisi.pendapatan/2010/2 7 hotml27 Desember 2011

Pengertian statistik deskriptif, diambil dari www.google.com, hotml 19 Januari 2011

Qardawi Yusuf, Hukum Zakat (Jakarta : PT. Pustaka Litera AntarNusa ) Edisi Ke-12, 2011

Ronny Kountour, Metode Penelitian untuk Penulisan Skripsi dan Tesis, (Jakarta : PPM), 2003

Tedy Herlambang dkk, Ekonomi Makro Teori, Analisis dan Kebijakan (Jakarta : PT Gramedia Pustaka Utama), 2001

TNI Markas Besar Angkatan Darat, "Organisasi dan Tugas Peralatan KODAM (Orgas Paldam)", Jakarta: Konfidensial, 2006

Wikipedia,2012,TentaraNasionalIndonesia[o nline],http://id.wikipedia.org/wiki 